\title{
Customer Perception Towards Online Shopping in Chennai City
}

\author{
Wilson Paul
}

\begin{abstract}
Online based purchasing is the way toward buying products and enterprises from traders who sell them online through Internet. Since the rise of the World Wide Web, sellers have tried to offer their items to individuals who browser the Internet. Customers can visit online stores from their homes and shop comfortably. Presently a day shopping has turned out to be mainstream among individuals through browsing which has increased their web knowledge and effective utilization of internet. So internet shopping has become accustomed to the buyers which made the researcher to study the perception on internet based shopping. The principle aim of the this research is to find out the opinion of the respondents towards internet shopping. These days, there has been a flood in web based shopping. The Internet has been utilized by clothing organizations to sell their items and advance their brands. As an ever increasing number of individuals purchase attire on the web, there have been an expanding number of inquires about.
\end{abstract}

Keywords: Online shopping, Customers, Shoppers, World Wide Web.

\section{INTRODUCTION}

The Retail trade now faces a colossal change. The impact of the alteration in the setup of the retail sector changed the way of life of the consumers of our country surely. Recently the buyers in our country are having enough awareness about the product that are being sold in retail through internet. These are the visible changes that are seen in our economy in retail section. The dealt with retail sector is relying upon to turn out to be more grounded than GDP improvement in the accompanying five years driven by developing lifestyles, blooming pay and incredible measurement plot. Mohanty and Panda (2008) opines about retailing as a segment of methodology of the nation. India is seeing retailing blast being moved by expanding urbanization, rising buying power equality (PPP) of regularly developing India's white collar class, changing statistic profiles vigorously tilted youthful populace, mechanical transformation, extreme globalization drive and so forth.

A position of business generally possessed and worked by a retailer however here and there claimed and worked by a maker or by somebody other than a retailer in which product is sold essentially to extreme shoppers. A huge retail complex

Revised Manuscript Received on December 05, 2019.

* Correspondence Author

Dr. Wilson Paul*, Associate Professor, Department of Corporate Secretaryship, KCSKN College, Chennai, India.

E-mail: cwilsonpaul@yahoo.com India possesses significant spot in the financial development

containing an assortment of stores and regularly eateries and different business foundations housed in a progression of associated or nearby structures or in a solitary enormous structure.

\section{REVIEW OF LITERATURE}

Rajah, R. K. (2018) The examination was completed with the point of understanding the purpose for consumer loyalty's towards internet shopping. Web based shopping is a type of electronic trade which enables the customer to purchase products or administrations from advertisers utilizing sites over the web. Advertisers and analysts mean to examine and comprehend factors that impact consumer loyalty towards web based shopping. This investigation centers around consumer loyalty and the impact of four elements which are web composition, protection and security.

Fullerton, G. (2005) The investigation was completed with the point of understanding the explanation for consumer loyalty's towards web based shopping. Web based shopping is a type of electronic trade which enables the purchaser to purchase products or administrations from advertisers utilizing sites over the web. Advertisers and specialists expect to investigate and comprehend factors that impact consumer loyalty towards web based shopping. This examination centers around consumer loyalty and the impact of four components which are web composition, protection and security.

\section{OBJECTIVES OF THE STUDY}

- To analyze the public attitude with reference to online based shopping.

- To study the impact of online shopping.

- To study about the customers satisfaction with reference to online based shopping

- To know about the customers opinion about online based shopping.

\section{SCOPE OF THE STUDY}

- Survey is done through distribution questionnaire for gathering primary data from 100 respondents.

- The study reveals the areas that needs to be improved to make advertisement more effective.

- The study helps to identify customers satisfaction towards the online shopping experience.

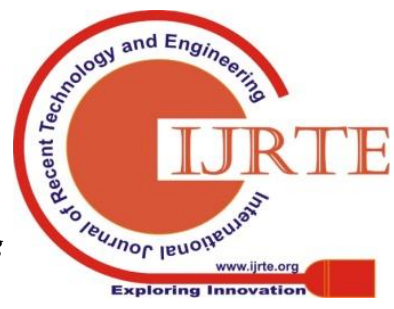


- The study helps to measure expectation level of customers with regard to online shopping.

\section{METHODOLOGY}

The investigation has been embraced by overview technique. 100 respondents were chosen by utilizing sampling technique, both primary and secondary data were used. A properly designed questionnaire was used to collect the relevant information for the study from the customers of Chennai city alone. The secondary data was gathered from the books, magazines, articles and web-based interfaces. For this analyst used the chi-square test, correlation, ANOVA and t-tests.

\section{RESULTS AND DISCUSSIONS}

In order to fulfill the above objectives, and to analyse the customers awareness, ideas, opinions and satisfaction about the online shopping and also analyse the demographic factor and level of satisfaction of customer of online shopping.

\section{Table - 1: Cross tabulation for age and sources of the knowledge about online shopping}

\begin{tabular}{|c|c|c|c|c|c|}
\hline \multirow{2}{*}{$\begin{array}{c}\text { Period } \\
\text { (year) }\end{array}$} & \multicolumn{5}{|c|}{ Source of knowledge } \\
\hline & $\begin{array}{l}\text { Smart } \\
\text { phones }\end{array}$ & Advertisements & Websites & $\begin{array}{c}\text { Friends } \\
\text { \&relatives }\end{array}$ & Total \\
\hline $\begin{array}{l}\text { Up to } \\
25\end{array}$ & $\begin{array}{c}2 \\
(50.0)\end{array}$ & $\begin{array}{c}1 \\
(25.0)\end{array}$ & - & $\begin{array}{c}1 \\
(25.0)\end{array}$ & $\begin{array}{c}4 \\
(100.0)\end{array}$ \\
\hline $26-35$ & $\begin{array}{c}8 \\
(53.3)\end{array}$ & $\begin{array}{c}2 \\
(13.3)\end{array}$ & $\begin{array}{c}1 \\
(6.7)\end{array}$ & $\begin{array}{c}4 \\
(26.7)\end{array}$ & $\begin{array}{c}15 \\
(100.0)\end{array}$ \\
\hline $36-45$ & $\begin{array}{c}14 \\
(33.3)\end{array}$ & $\begin{array}{c}11 \\
(26.2)\end{array}$ & $\begin{array}{c}11 \\
(26.2)\end{array}$ & $\begin{array}{c}6 \\
(14.3)\end{array}$ & $\begin{array}{c}42 \\
(100.0)\end{array}$ \\
\hline $46-55$ & $\begin{array}{c}9 \\
(26.5)\end{array}$ & $\begin{array}{c}11 \\
(32.4)\end{array}$ & - & $\begin{array}{c}14 \\
(41.2)\end{array}$ & $\begin{array}{c}34 \\
(100.0)\end{array}$ \\
\hline $\begin{array}{l}\text { Above } \\
55\end{array}$ & $\begin{array}{c}2 \\
(40.0)\end{array}$ & $\begin{array}{c}1 \\
(20.0)\end{array}$ & - & $\begin{array}{c}2 \\
(40.05)\end{array}$ & $\begin{array}{c}5 \\
(100.0)\end{array}$ \\
\hline Total & $\begin{array}{c}35 \\
(35.0)\end{array}$ & $\begin{array}{c}26 \\
(26.0)\end{array}$ & $\begin{array}{c}12 \\
(12.0)\end{array}$ & $\begin{array}{c}27 \\
(27.0)\end{array}$ & $\begin{array}{c}100 \\
(100.0)\end{array}$ \\
\hline
\end{tabular}

The above table found that, the sources of the knowledge about online shopping based on the age group. Among the 4 respondents represented the age group on up to 25 years, 15 respondents represented the age group of 25-35 years, 42 respondents represented the age group of 35-45 years, 34 respondents represented the age group of 45-55 years and only 5 respondents represented the age group of above 55 years.

Table - 2: Chi-square test

\begin{tabular}{|l|l|l|l|}
\hline & Value & df & $\begin{array}{l}\text { Asymp. Sig. } \\
\text { (2-sided) }\end{array}$ \\
\hline
\end{tabular}

\begin{tabular}{|l|l|l|l|}
\hline Person & & & \\
Chi-square & $21.927 \mathrm{a}$ & & \\
Likelihood ratio & 25.494 & 12 & .038 \\
Linear-by-linear & 2.027 & 12 & .013 \\
Association & 100 & 1 & .154 \\
N of valid & & & \\
Cases & & & \\
\hline
\end{tabular}

From the chi-square test, the significance value 0.038 which is less than 0.05 , there is significant association between age and source of the knowledge about the online shopping hence the hypotheses rejected.

\section{Percentage opinion score about online shopping}

\section{Percentage score}

The consumers' opinion of price, quality and delivery of products through online shopping can be added and it is used for testing the average percentage opinion score about online shopping practices among the various educational level of the respondents. The results of one-way ANOVA is given below

\section{One-way}

Table - 3: ANOVA

\begin{tabular}{|c|l|c|c|c|c|}
\hline & \multicolumn{1}{|c|}{$\begin{array}{c}\text { Sum of } \\
\text { squares }\end{array}$} & df & $\begin{array}{c}\text { Mean } \\
\text { square }\end{array}$ & F & Sig. \\
\hline Between & 1177.329 & & & & \\
Groups & 12113.67 & 3 & 329.443 & 3.110 & .030 \\
Within & 1 & 96 & 126.184 & & \\
Groups & 13291.00 & 99 & & & \\
Total & 0 & & & \\
\hline
\end{tabular}

From the ANOVA table, the significance value 0.030 which is less than 0.05 , the level of significance we conclude that the alternative hypothesis is accepted which means that there is significant relationship between online shopping practices and education levels of the respondents.

\section{RECOMMENDATIONS}

- The need of the hours is to have an effective distribution network, so that supplies reach the dealers had in time to customers.

- The publicity of advertisement not reached to the all areas especially to rural areas. So the advertisement can be improved for online based shopping by the companies.

- The brand of certain online based shopping companies is in great demand especially Flipkart, Amazon etc. The delay in the delivery of products the customer's to go in for other brand. If the delivery position is further improved, there will be substantial increase in sales.

- Internet providers must improve the speed of data which improve the online shopping. 
- The companies must train the customers in usage of online shopping facilities.

\section{CONCLUSION}

Online shopping which has already created a corporate image among the consumer, should come out which massive advertising campaign and multi - number of firms in each size. This will result in "TRY MY PRODUCT" than the present stage of "BUY MY PRODUCT". Moreover through advertisements, consumers will automatically move towards the products.

To overcome the heavy competition in the industry, online shopping has to strengthen up weak areas like after sales service, advertisement and varieties of models as far as consumers are concerned. Online shopping companies has to create perception of it in consumer's mind that can be easily distinguishable from other competing brands. To withhold the current position in the market and their strong areas like brand loyalty, corporate image etc., online shopping companies should try create a new game pillar. If this happens, then online shopping will definitely become the "Pride of Deccan".

\section{REFERENCES}

1. Fullerton, G. (2005). The service quality-loyalty relationship in retail services: does commitment matter?. Journal of Retailing and Consumer Services, 12(2) 99-111.

2. Goswami, S., \& Mathur, M. (2011). Retail Goes Online-An Indian Perspective. International Journal of Management and Tourism, 19(2), $1-11$.

3. Khan, M. S., \& Mahapatra, S. S. (2009). Service quality evaluation in internet banking: an empirical study in India.

4. Kothari, C. R. (2004). Research methodology: Methods and techniques. New Age International.

5. Rajah, R. K. (2018). Customer Satisfaction towards Online Shopping (Doctoral dissertation, Multimedia University).

\section{AUTHOR PROFILE}

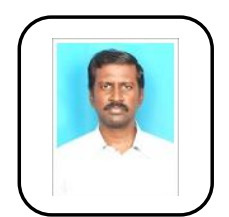

Dr. Wilson Paul, is working as a Associate professor in The Department of Corporate Secretaryship, K.C.S. Kasi Nadar College of Arts \& Science, Chennai. He was awarded Ph.d Degree in Corporate Secretaryship by Manonmanian Sundaranar University, Tirunelveli, for research work in Marketing. He has 19 years experience.

He published more than 25 articles. $\mathrm{He}$ is active in Placement and future career of the students. 